International Journal of Business Management and Economic Review

Vol. 4, No. 05; 2021

ISSN: 2581-4664

\title{
INFLUENCE OF INFORMATION CAPITAL READINESS ON IMPLEMENTATION OF CUSTOMER ASSET MANAGEMENT BY SACCOS LICENSED TO UNDERTAKE DEPOSIT-TAKING IN KENYA
}

\author{
Dr. Caleb Odhiambo Onjure, PhD. \\ Lecturer, Africa International University Nairobi, Kenya \\ Ms Faith Mukonyo Muia \\ $\mathrm{PhD}$ Student Jomo Kenyatta University of Agriculture and Technology \\ Prof. Erick Aseka \\ Lecturer, Africa International University Nairobi, Kenya \\ http://doi.org/10.35409/IJBMER.2021.3314
}

\begin{abstract}
Businesses are thinking hard now on how to break even during uncertainties that has made planning and strategic decisions difficult. Survival has become tough in the financial sector worldwide and leaders must think creatively and flexibly. This has been catalyzed by the spread of COVID-19. For survival, the SACCOs are looking into a future of revolution that will takes them to next level through approaches like web and mobile banking applications to embrace world class technology, affordable and flexible systems, no hidden costs, $100 \%$ customized processes and unbeatable time to the market. The SACCOs must re-strategize on how to stay afloat. The main objective of the study was to determine the influence of information capital readiness on implementation of customer asset management in SACCOs licensed to undertake deposit taking in Kenya. Specifically, the study investigated the influence of IT infrastructure, IT transformational application, IT analytical application, and IT transaction processing application on customer asset management by SACCOs licensed to undertake deposit-taking in Kenya. The study employed descriptive research design. The study population was 175 and carried out a census survey on the same. The study established that information capital readiness has significant influence customer asset management by licensed deposit taking SACCOs in Kenya. The study found that there is a negative insignificant influence of IT transformation application on customer asset management. The study concluded that there were gaps in areas such as training, innovativeness, risk management, scenario planning, and general management. The study recommended leverage on technology, member development and staff training, intensifying monitoring and evaluation/ control, process reengineering, and proper data management. The study recommends for reengineering on IT analytical application and IT transformational applications processes. This will involve radical thinking and re-designing modern technology available.
\end{abstract}

Keyword: Information Capital, Customer Asset Management, It Infrastructure, Analytical Application, Transformational Application, Transactional Processing Application.

\section{INTRODUCTION}

\subsection{Background of the Study}

COVID19 pandemic is a multifaceted crisis that has affected socio-economic, political and 


\section{International Journal of Business Management and Economic Review}

Vol. 4, No. 05; 2021

ISSN: 2581-4664

health sectors among many others. This has resulted to parent organizations folding up, job losses, lost income, inability of service loans, morale employee morale, and non-effective working conditions (Karimi, 2021). The global economy is changing at an extraordinary pace (Sarokin, 2019), and business organizations must survive these current dynamic and turbulent challenges in order to achieve competitive advantage against their competitors (Reeves \& Deimler, 2011). Survival and success have become a challenge which is the reality of most firms today, due to the impact of COVID 19 (Survival strategies for businesses during COVID-19 lockdown, 2020). The global trend in business and industry has continued to be characterized by swift dynamism (Henry-Nickie, Frimgpong, \& Sun, 2019). Avigoke, Auma and An'gon'ga (2019), asserted organizations are forced to devise and implement strategies focused on combating and mitigating challenges caused by this turbulence (Kotter \& Schlesinger, 2008). Financial organizations must direct their energies in maximizing returns while reducing the risks associated with the return-earning process (Kelton \& Scott, 2020). Based on financial stewardship theories interpretation, the SACCOs, which play key role in Kenya's economic strategy and bolstering income generating opportunities (contributing to around 5.7\% of the country's GDP), is struggling to maximize their market value of net wealth (De Falco \& Renzi, 2015). The maximization of customer value is still the driving force for management as they make various financial decisions regarding how the SACCOs should run (Paine \& Srinivasan, 2019).

\subsubsection{SACCOs Performance in Kenya}

In Kenya, SACCOs are one of the leading sources of rural finance and in many rural areas the local SACCO is the only provider of financial services (Wasonga, 2020). They form an important part of deposit-taking and lending market in Kenya, providing financial services to around six million households across the country (Karimi, 2021). SACCOs are therefore one of the best vehicles for driving socio-economic development in Kenya (Otieno, 2019). The SACCOs benefits members by providing higher returns on their deposits through interest credited on their accounts, lower rates on loans, and many more than financial services, that members seek to improve their livelihood enabling them to own homes, fund children education and help in business start-up (WCOCU, 2014). According to Statistics there are 10,800 registered Co-operative Societies in Kenya with a membership of about 6 million. Out of this, 46\% are Agricultural, 38\% Financial based (SACCOS) and, 16\% are others (Kasyoka, 2016; Momanyi, 2014).

The number of SACCOs rose from 630 in 1978 to 4,500 by December 31st, 2004. Over the same period, savings and share capital rose from kshs: 375 million to kshs: 150 billion by December 2004. SACCOS' membership numbered over 3 million by December 2004 having risen from 387,500 members in 1978. With savings of Kshs.380 billion and asset base of Kshs.493 billion, SACCOs control 39 percent of total loan accounts in Kenya (SASRA, 2012). Lending is the main business of SACCOs with loans forming the main source of revenue (Maina, Kinyariro, Muturi, \& Muriithi, 2016; Wanyoike \& Kiptoo, 2015). With more than twenty-five percent of the world population being referred to as unbanked, there is need for SACCOs to mobilize more members to access finance especially the unemployed and underemployed youth in Africa (Ndungo, Olweny, \& Memba, 2018; KUSCCO, 2014).

In addition to COVID 19, the current highly dynamic market trends brought about by globalization, liberalization of financial market, and rapidly changing technologies, among 


\section{International Journal of Business Management and Economic Review}

Vol. 4, No. 05; 2021

ISSN: 2581-4664

others have created diverse pressure and challenges on cooperatives in the developing countries (Treverton, 2015). Banks and micro-finance institutions have become stiff competitors to SACCOs (Mudibo, 2009; Mutai, Asienga, \& Kirui, 2016). Banks and the telecommunications service provider companies are also borrowing ideas from the cooperative business model in their target markets. Members similarly join SACCOs which have been profitable due to their going concern basis (Myers, 2012; Chepkemoi \& Mwangi, 2017).

Most of the cooperative's problems or challenges mainly arise from poor management and lack of management skills, lack of competitive market to sell theory product (Mhembwe \& Duba, 2017) and governance (Nkuru, 2015; Mutunga, 2009), weak legislation (Reporter, 2018), poor financial management, leadership, governance and political interference (Baka, 2013). The sector has limited marketing structures, low levels of income, a weak capital base and leadership capacity, and poor management. Due to this, performance has gradually declined and thus many cannot compete effectively (Mwangi \& Ogutu, 2008). Mudibo (2005) stated that the cooperative societies are mainly used for wealth creation among its members. Small loans at very low interests improve the financial performance of SACCOs on different scenario. Sinani (2007) argued that the land buying cooperatives are allegedly defrauding their members, and nearly all the cotton cooperatives have collapsed and many credit unions are experiencing problems arising from favoritism in approval of loans, making the firms to have low income due to poor performance. Finding by Mwangi and Regina established that poor management affects negatively the growth of SACCOS in Kenya (Regina \& Mwangi, 2017; Jones, 2007).

In addition, SACCOs have not been adequately responsive to the changing external environment hence affecting their growth (Nkuru, 2015; Maina, 2008). Byrne, Power, McCarthy \&Ward (2010), in their study on "the potential of credit unionism providing their members with financial capability", concluded that credit unions engage in educating the community financially, but most are low-commitment activities. Few credit unions have come up with innovative schemes targeted at their members. According to the Sacco Annual Supervision Report (2016), the DTSs loan portfolio risk increased to 5.23 per cent up from 5.12 in 2015 , with the value of nonperforming loan increasing from Sh13.21 billion to Sh15.57 billion. The loan portfolio risk of 5.23 per cent was higher than five per cent recommended maximum by the World council of Credit Unions and three per cent recommended by the local Sacco regulator (SASRA, 2016).

According to Mugo, Muathe, \& Waithaka, (2019), deposit-taking SACCOs in Kenya are categorized into teacher-based, government based, farmer-based, private institution-based and community-based SACCOs. Government-based SACCOs membership comprise of employees from government ministries, departments, state corporations, public universities and colleges, and county governments (Okoth, 2019). Farmer-based SACCOs, majority of members are engaged in agricultural activities. Private institution based SACCOs members are mainly employees of private organizations operating. Community-based SACCOs members are mainly residents of a geographical area, and engaged in an economic activity, while teacher based SACCOs draws memberships from employees of public/private schools, colleges, and universities (Mugo, Muathe, \& Waithaka, 2019).

\subsubsection{The Concept of Information Capital Management}

The concept asserts that information has intrinsic value which can be shared and leveraged within and between organizations. It enables the sharing of knowledge capital. It is derived from information systems. Sharing information means of sharing power, supporting personnel, and 


\section{International Journal of Business Management and Economic Review}

Vol. 4, No. 05; 2021

ISSN: 2581-4664

optimizing working processes (Kosuga, Monden, \& Monden, 2007). Information capital is a core livelihood asset, and it means different kinds of data endowed with relevance and purpose is used to make decisions in pursuit of target objectives (Odero, 2006). Information Capital (IC) is an essential input for creating value in an economy. It however has value only in the context of the strategy, for it makes information and knowledge available to the organization. An organization pursuing a low total cost strategy gets the highest returns from information systems that focus on quality, process improvement, and workforce productivity (Sergio, 2011). A customer solutions strategy benefits most from information systems that reveal knowledge about customer preferences and behavior, and that enhance customer contact, service, and retention (Kulbyte, 2020). Similarly, information capital enables the exchange of knowledge capital (a set of data valuable for the organizations that can be reached through data storage system). The information systems and data bases are integrated into organization systems to support processes. Sharing of information optimizes working processes.

Clinck and Lombardi (2011) in their investigation on the impact of endogenous information acquisition on Easley and O'Hara's (2004) established that moving information from being publicly to privately available, results in an increase in a firm's cost of capital. From their study further findings, when the cost of information acquisition is fixed, Easley and O'Hara's result reversed. They did a study on two scenarios, however, where Easley and O'Hara's result can continue to hold only where the cost of information acquisition is increasing in its precision, and where the benefits of acquiring private information span multiple firms (Clinch \& Lombardi, 2011).

According to Odero (2006), information has been defined differently by many people: as thing, as resource, as commodity, as reduction of uncertainty, as the statistical probability of a sign or signal being selected from a given set of signs or signals, as a constitutive force in society; as data endowed with relevance and purpose, and as an intangible, which involves either the telling of something or that which was being told. They become capital or resources owing to the value attached to them and the uses they are put to. The World Development Report (1998/99) argued that information is the lifeblood of every market (World Bank, 1998-1999). According to the World Bank, information problems are likely to result into market failures and inefficiency and poor growth. It results into economic imbalance that leads to total market failure. The embedded nature of information capital requires that individuals exercise their cognitive skills in such a way that they can understand, explain, compare and evaluate information (UNESCO, 2002). Computer-based technology offers new competitive opportunities, and companies use it to build barriers to entry, build in switching costs, and even completely change the basis of competition. Though supplier-customer links, it avails opportunity for a competitive edge, but at the same time bring a risk of strategic vulnerability (McFarlan, 1984).

\subsection{Statement of the Problem}

The cooperative sector in Kenya is currently worth $\$ 10$ billion in asset and employs more than 500,000 directly and another 1.5 million indirectly. The total revenue of the cooperative sector is approximately Ksh 173.26 billion, with accumulated deposits of approximately Ksh844.5 billion. SACCOs have improved lives of many by grating loans and offering direct and indirect employment opportunities; a move to realization of Vision 2030. The saving and deposits are estimated at over $\$ 7$ billion, and loan portfolio is in excess of $\$ 6.6$ billion. However, there are challenges; according to Douglas, Philip and Nafula (2018), the management has affected the 


\section{International Journal of Business Management and Economic Review}

Vol. 4, No. 05; 2021

ISSN: 2581-4664

performance of SACCOs. The SACCOs have failed in addressing the overtime engagement as they failed to compensate their employees (part of internal customers) who resultantly become less efficient, less productive and very dissatisfied. SACCOs in Kenya also faces challenges of poor accounting systems and record keeping, poor loan recovery due to defaulters, state agencies and private companies to remit statutory deduction on time, weak laws, limited product development, weak controls and mismanagement (recruitment of staff), viability of major projects, members apathy (dominant members) liquidity problems (capital requirement ratio), failure by employers to remit deductions (currently to the tune of $\$ 26.7$ million) is increasingly becoming a big threat to the survival of many SACCOS, corruption, lack of professionalism, non-adherence to cooperative principle (autonomy \& independence, member democratic control, and voluntary joining of SACCOs), reckless lending, delays in reimbursement of deposits, inflated charges,competition from financial institutions (banks and mobile banking), and internal politics. They also experience efficiency challenges characterized by poor information delivery channels and high operational costs due to inadequate information and communication technologies, they face high demands for loans they are unable to meet due to liquidity shortages, hence compromising their profitability (especially given that they cannot seek credit from the Central Bank of Kenya like other commercial banks. According to the 2016 Sacco Annual Supervision Report, the DTSs loan portfolio risk increased to 5.23 per cent up from 5.12 in 2015, with the value of non-performing loan increasing from Sh13.21 billion to Sh15.57 billion. Kericho County Director of cooperatives Mr. Leonard Otii advised SACCOs affiliated to giant multinationals to device other means of survival in face of dwindling membership. Minimal research has been carried out in information capital readiness and its influence in customer asset management. The study was to fill the gap by determining the influence of information capital on customer management by SACCOs in Kenya.

\subsection{Research Objectives}

These include both the general and specific objectives.

\subsubsection{General Objective of the Study}

The general objective of the study was to determine the influence of information capital on customer asset management by SACCOs licensed to undertake deposit-taking in Kenya.

\subsubsection{Specific Objectives}

The specific objectives include:

i. To examine the influence of IT infrastructure on customer asset management by SACCOs licensed to undertake deposit-taking in Kenya.

ii. To evaluate the influence of transformational application on customer asset management by SACCOs licensed to undertake deposit-taking in Kenya.

iii. To determine the influence of analytical application on customer asset management by SACCOs licensed to undertake deposit-taking in Kenya.

iv. To assess the influence of transaction processing application on customer asset management by SACCOs licensed to undertake deposit-taking in Kenya.

\subsection{Research Hypotheses}

The following hypotheses were tested at the 0.05 level of significance:

$\mathrm{H}_{01}$ : There is no significant influence of IT infrastructure on customer asset management by SACCOs licensed to undertake deposit-taking in Kenya. 


\section{International Journal of Business Management and Economic Review}

Vol. 4, No. 05; 2021

ISSN: 2581-4664

$\mathrm{H}_{01}$ : There is no significant influence of IT transformational application on customer asset management by SACCOs licensed to undertake deposit-taking in Kenya.

$\mathrm{H}_{01}$ : There is no significant influence of IT analytical application on customer asset management by SACCOs licensed to undertake deposit-taking in Kenya.

$\mathrm{H}_{01}$ : There is no significant influence of IT transaction processing application on customer asset management by SACCOs licensed to undertake deposit-taking in Kenya.

\subsection{Significance of the Study}

The study is relevant to the following stakeholders: this study is of help to the government of Kenya as it sought to leverage on technology strategy to grow the financial services sector and enhance financial access and inclusion. Through the findings of the study, the government of Kenya can appreciate which strategic areas to support the SACCO sector. The study findings should help SACCOs in evaluating the role of information capital on their performance with reference to customer asset management. SACCOs, especially deposit-taking ones, are swiftly becoming more aware of the customer management in this era and this study adds impetus to knowledge on the link between information capital readiness and customer relationship management. To scholars, the study is value-added to the existing body of knowledge in area of strategic management, as it recommends ways for improving information capital management and customer management by leveraging on information capital readiness to enhance customer asset management in organizations. This study serves as a steppingstone for newer research on strategic management systems.

\subsection{Scope of the Study}

The study covered 175 registered deposits taking SACCOs registered by SASRA of Kenya. The SACCOs that formed the units of analysis of the study are those that were in operation by close of business of 31st December 2019. The study will determine the influence of information capital readiness on customer asset management in SACCOs licensed to undertake deposittaking in Kenya. The independent variables under the study are IT infrastructure, IT transformation application, IT analytical application, and IT transaction application. Data collection was conducted in the year 2021. Both qualitative and quantitative approaches will be applied. The study utilized both primary and secondary data. The budget for this study was ksh. 250,000 .

\subsection{Limitations of the Study}

The challenges encountered during the study included financial, given the rising cost of materials in Kenya today and transportation. Furthermore, the subject of the study was sensitive and making appointment with some respondents caused some delays. However, the researcher encouraged the respondent to corporate for better results. 
International Journal of Business Management and Economic Review

Vol. 4, No. 05; 2021

ISSN: 2581-4664

\section{THEORIES REVIEWED}

The study will be guided by five theories: Resource Based View Theory, Complexity Theory, Theory of Change, Theory of Planned Behavior, and Innovation Diffusion Theory.

\subsection{Conceptual Framework}

\section{IT Infrastructure \\ $>$ Network structure \\ $>$ Communication protocols \\ $>$ Web standards \\ $>$ Security systems}

\section{IT Transformational Application}

$>$ Customer self help

$>$ Customer portfolio management
Implementation of Customer Asset

Management in licensed to undertake deposit taking SACCOs in Kenya

$>$ online customer service and support

$>$ Market intelligence.

$>$ Marketing management.

$>$ Online salesforce automation

\section{IT Transactional Processing Application \\ $>$ Problem management system \\ $>$ Incident tracking system \\ $>$ Integrated customer file \\ $>$ Real time transaction Processing \\ $>$ Batch Transaction Processing \\ $>$ Managing communication \\ $>$ Managing data \\ $>$ Monitoring \\ $>$ Managing system resources \\ $>$ Scheduling and load balancing}

\section{RESEARCH DESIGN}

Research design, according to Waiganjo (2013) is a framework that guides the collection and analysis of the data, and a detailed plan for how research study is conducted in order to investigate the research questions. The study will employ a descriptive survey research design. This is because; it permits the collection of data through questionnaires administered to a sample quickly, efficiently, and accurately (Osoo \& Onen, 2007).

\subsection{Target Population}

Target population is lager group of items to which the research finally would like to generalize 
Vol. 4, No. 05; 2021

ISSN: 2581-4664

the findings of the study (Berg, 2001 as cited in Okello, 2017). In this study, the target population will be all (175) SACCO societies licensed to undertake deposit-taking SACCO business in Kenya as was duly published in the Kenya Gazette No. 572 dated 25th January 2019.

The study will target one manager in every SACCO. The total accessible target population of 175 managers is targeted. The target population is stratified as shown in Table 3.1.

Table 3.1: Target Population

\begin{tabular}{|ll|}
\hline Cadre of SACCO & Population \\
\hline $\begin{array}{l}\text {-Licensed SACCO societies with } \\
\text { conditions attached for the period ending }\end{array}$ & \\
31 st December, 2019 & 163 \\
-licensed SACCO societies for period & \\
$\begin{array}{l}\text { ending 31st December, 2019 } \\
\text {-licensed SACCO societies restricted to } \\
\text { the period ending 30th June, 2019 }\end{array}$ & 11 \\
\hline Total & $\mathbf{1 7 5}$ \\
\hline
\end{tabular}

Source: Kenya Gazette No. 572 dated 25th January 2019.

\subsection{Sample Size and Sampling Technique}

\subsubsection{Sample Size}

Sample size is a statistically suitable group to collect data from which can be generalized to represent an entire target population (Dessel, 2013). In this study, a sample size of 175 will be used.

\subsubsection{Sampling Technique}

Sampling Technique however refers to a definite for obtaining a sample from a given population (Kothari, 2004). It is the procedure the researcher will use in selecting items for the sample. The study will conduct a census survey on all the 175 dully published SACCOs in the Kenya Gazette number 572 dated 25th January 2019.

\subsection{Data Collection Instruments}

The study used questionnaires to obtain both qualitative data and quantitative. Malhotra (2011) held questionnaire as an important data collection tool. The researcher also used the Likert (1932) scale type of questions.

\subsection{Pilot Test}

Reliability and validity of the questionnaire was measured. 20 SACCO managers from the 20 registered non-deposit taking SACCOs, like the final study respondents, and who were not part of the main study were randomly selected for the survey. In order to achieve a high precision pilot studies $1 \%$ to $10 \%$ of the sample should constitute the pilot test size (Arain, Campbell, Cooper \& Lancaster, 2010). Total of 20 SACCOs constituted $11.63 \%$ of the 175 deposit taking registered SACCOs which was greater than the recommended 1-10\% of the sample size. 
International Journal of Business Management and Economic Review

Vol. 4, No. 05; 2021

ISSN: 2581-4664

\subsubsection{Reliability}

The measurement of reliability provided consistency in the measurement of variables. From Table 3.3 the Cronbach alpha $(\alpha)$ was above recommended standard minimum of 0.7 .

Table 3.1: Reliability Test

\begin{tabular}{lll}
\hline Study Variable & Number of Test & Cronbach Alpha \\
\hline IT infrastructure & 36 & 0.7542 \\
IT transformational application & 19 & 0.8257 \\
IT analytical application & 16 & 0.7587 \\
IT transaction processing application & 19 & 0.8266 \\
Customer Asset Management & 9 & 0.8324 \\
\hline
\end{tabular}

\subsubsection{Validity of the Research Instrument}

The study used both construct validity and content validity. For construct validity, the questionnaire was divided into five sections to ensure that each section assessed information for a specific objective of the study. To ensure content validity, the questionnaire was subjected to thorough examination by four randomly peers and selected management experts. The instrument was adjusted appropriately before being subjected to final data collection exercise. The review comments were used to ensure that content validity was improved.

\section{RESPONSE RATE}

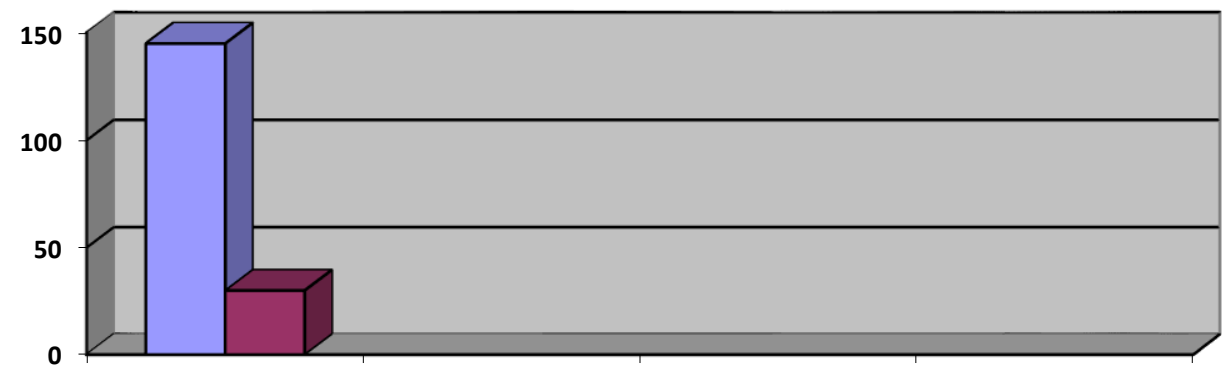

\section{Figure 4.1}

Out of 175 questionnaires issued, 145 were returned. In percentage was $83 \%$ response. Respondent response of 50\% is adequate (Mugenda \& Mugenda, 2003).

4.2 Descriptive Analysis

4.2.1 IT Infrastructure

Q1. Technological foundation of computer, communications, data, and basic systems as a strategic choice towards acquiring, retaining, and winning back customers.

Table 4.1

\begin{tabular}{|c|c|c|c|}
\hline & $\mathbf{N}$ & Mean & $\begin{array}{l}\text { Std. } \\
\text { Deviatio } \\
\text { n }\end{array}$ \\
\hline $\begin{array}{l}\text { Development of systems that can configure themselves, he } \\
\text { themselves }\end{array}$ & $\begin{array}{l}14 \\
5\end{array}$ & $\begin{array}{l}3.363 \\
6\end{array}$ & 1.02525 \\
\hline
\end{tabular}




\begin{tabular}{|c|c|c|c|}
\hline Company has enough computing power for current and future needs & $\begin{array}{l}14 \\
5\end{array}$ & $\begin{array}{l}3.424 \\
2\end{array}$ & 1.22552 \\
\hline $\begin{array}{l}\text { Data across applications and operating systems has consistency and } \\
\text { integrity, and can be shared across applications and operating } \\
\text { systems }\end{array}$ & $\begin{array}{l}14 \\
5\end{array}$ & $\begin{array}{l}3.515 \\
2\end{array}$ & 1.14895 \\
\hline $\begin{array}{l}\text { More sophisticated computers used for tasks requiring extremely } \\
\text { rapid and complex calculations with thousands of variables, millions } \\
\text { of measurements }\end{array}$ & $\begin{array}{l}14 \\
5\end{array}$ & $\begin{array}{l}3.727 \\
3\end{array}$ & 1.15306 \\
\hline $\begin{array}{l}\text { Customers use infrastructure and programming tools hosted by the } \\
\text { service provider to develop own applications. }\end{array}$ & $\begin{array}{l}14 \\
5\end{array}$ & $\begin{array}{l}3.757 \\
6\end{array}$ & 1.00095 \\
\hline $\begin{array}{l}\text { Extraordinary efforts are taken to make redundant copies of digital } \\
\text { information, and placing it on separate secure servers, even remote } \\
\text { servers in separate facilities. }\end{array}$ & $\begin{array}{l}14 \\
5\end{array}$ & $\begin{array}{l}3.787 \\
9\end{array}$ & 1.19262 \\
\hline $\begin{array}{l}\text { Implementing hardware/software that are reputable or based on } \\
\text { current technological trends }\end{array}$ & $\begin{array}{l}14 \\
5\end{array}$ & $\begin{array}{l}3.878 \\
8\end{array}$ & 1.08275 \\
\hline $\begin{array}{l}\text { Used to analyze direct and indirect costs to help determine the actual } \\
\text { cost of owning a specific technology }\end{array}$ & $\begin{array}{l}14 \\
5\end{array}$ & $\begin{array}{l}3.878 \\
8\end{array}$ & .96039 \\
\hline $\begin{array}{l}\text { We have sufficient computer processing, storage, and network } \\
\text { resources to handle surging volumes of digital transactions and to } \\
\text { make such data immediately available online. }\end{array}$ & $\begin{array}{l}14 \\
5\end{array}$ & $\begin{array}{l}3.909 \\
1\end{array}$ & 1.01130 \\
\hline $\begin{array}{l}\text { Hardware/software are easily and quickly adapted for changing } \\
\text { needs and standards }\end{array}$ & $\begin{array}{l}14 \\
5\end{array}$ & $\begin{array}{l}3.939 \\
4\end{array}$ & 1.17099 \\
\hline IT personnel quickly learn and apply new technologies & $\begin{array}{l}14 \\
5\end{array}$ & $\begin{array}{l}4.000 \\
0\end{array}$ & .82916 \\
\hline $\begin{array}{l}\text { Enhanced performance, reduced power consumption, and more } \\
\text { efficient simultaneous processing of multiple tasks }\end{array}$ & $\begin{array}{l}14 \\
5\end{array}$ & $\begin{array}{l}4.060 \\
6\end{array}$ & 1.05887 \\
\hline $\begin{array}{l}\text { Create electronic linkages among departments and branches as well } \\
\text { as external parties (e.g., customers, suppliers) }\end{array}$ & $\begin{array}{l}14 \\
5\end{array}$ & $\begin{array}{l}4.121 \\
2\end{array}$ & .92728 \\
\hline $\begin{array}{l}\text { IT infrastructures reduce storage costs, manage information, increase } \\
\text { flexibility, and provide near-certain backup. }\end{array}$ & $\begin{array}{l}14 \\
5\end{array}$ & $\begin{array}{l}4.272 \\
7\end{array}$ & .83937 \\
\hline $\begin{array}{l}\text { IT infrastructure should receive adequate attention and recognition at } \\
\text { the time of decision-making and in the planning and implementation } \\
\text { of business strategic and structural changes. }\end{array}$ & $\begin{array}{l}14 \\
5\end{array}$ & $\begin{array}{l}4.303 \\
0\end{array}$ & 1.04537 \\
\hline
\end{tabular}

The findings as in Table 4.1demonstrate that $68 \%$ of the respondents were within one standard deviation. The finding shows that in the effort to use technological foundation of computer, communications, data, and basic systems as a strategic choice towards acquiring, retaining, and winning back customers, IT personnel who serve in the SACCOs can quickly learn and apply new knowledge, and the SACCOs have achieved an enhanced performance, reduced power consumption, and more efficient simultaneous processing of multiple tasks. Similarly, the finding show that electronic linkages among departments and branches are created as well as for the external parties. Further, there is strategic reduction in storage costs, improved information management, increase flexibility, and near-certain backup. There was a general view that IT infrastructure should receive adequate attention and recognition at the time of decision-making 


\section{International Journal of Business Management and Economic Review}

Vol. 4, No. 05; 2021

ISSN: 2581-4664

and in the planning and implementation of business strategic and structural changes in the SACCOs.

However, in the processes of technological foundation of computer, communications, data, and basic systems as a strategic choice towards acquiring, retaining, and winning back customers, SACCOs have not developed proper systems that are able to configure themselves and heal themselves. Similarly, they lack enough computing power for current and future needs. Data across applications and operating systems have no sufficient consistency and integrity and cannot be shared across applications and operating systems. Less sophisticated computers are also now being used for tasks requiring extremely rapid and complex calculations with thousands of variables, millions of measurements. The finding further shows that extraordinary efforts are not being properly taken to make redundant copies of digital information, and placing it on separate secure servers, even remote servers in separate facilities.

The findings further shows that there was insufficient implementation of hardware/software that are reputable or based on current technological trends. The use of IT infrastructure to analyze direct and indirect costs that help determine the actual cost of owning a specific technology is not yet affected. Further findings shows that the SACCOs had insufficient computer processing, storage, and network resources to handle surging volumes of digital transactions and to make such data immediately available online. The hardware/software are also not easily and quickly adapted for changing needs and standards. Similarly, the SACCOs had not enough computer power for current and future needs.

Q2. Efforts to enhance the ability to easily and readily diffuse or support a wide variety of hardware, software, communication technologies, data, core applications, skills, competencies, commitments, values within the technical physical base and the human component of the existing IT infrastructure in your organization.

Table 4.2

\begin{tabular}{llll}
\hline & & & \multicolumn{3}{c}{$\begin{array}{l}\text { Std. } \\
\text { Deviatio } \\
\text { n }\end{array}$} \\
\hline Architecture and standards & N & Mean \\
IT Research and Design & 145 & 3.7576 & .83030 \\
IT education & 145 & 3.9394 & .89928 \\
Communication protocol and management & 145 & 3.9394 & .89928 \\
IT management & 145 & 3.9697 & .68396 \\
Application infrastructure & 145 & 4.0000 & .90139 \\
Facility management & 145 & 4.0303 & .68396 \\
Web standards & 145 & 4.0303 & .72822 \\
Network Structure & 145 & 4.0606 & .74747 \\
Security risk & 145 & 4.0606 & .70442 \\
Security system & 145 & 4.1515 & .93946 \\
\hline
\end{tabular}

From Table 4.2 shows that in efforts to enhance the ability to easily and readily diffuse or support a wide variety of hardware, software, communication technologies, data, core applications, skills, competencies, commitments, values within the technical physical base and the human component of the existing IT infrastructure, the SACCOs have developed security 
Vol. 4, No. 05; 2021

ISSN: 2581-4664

system and network structures, web standards, facility management, application infrastructure, IT management, and also looked into security risks.

However, the SACCOs are yet to investigate architectures and standards, IT research and design, and communication protocol and management.

Q3 Activities related to network structure, communication protocol, web standards and system security have played a positive role in improving customer asset management.

Table 4.3

\begin{tabular}{|llll|}
\hline & & & $\begin{array}{l}\text { Std. } \\
\text { Deviati } \\
\text { on }\end{array}$ \\
\hline Market management & $\mathrm{N}$ & Mean \\
Real time fraud analytics & 145 & 3.9394 & .99810 \\
Enhanced operational efficiency & 145 & 3.9697 & 1.10354 \\
Reduced time to market products & 145 & 4.0606 & .93339 \\
Market intelligence & 145 & 4.0909 & .97991 \\
Online sales force automation & 145 & 4.1212 & .96039 \\
Online customer support & 145 & 4.1515 & .90558 \\
Real time transaction flow & 145 & 4.1515 & .87039 \\
Faster payment & 145 & 4.1818 & 1.07397 \\
Enhancement of customer experience & 145 & 4.2121 & .78093 \\
\hline
\end{tabular}

From Table 4.3, enhancement of customer experience, faster payments, real time transaction flow, online customer support, online sales force automation, market intelligence, enhanced efficiency, and reduced time to market products have played a positive role in improving customer asset management in the SACCOs. However, market management and real time fraud analysis are to be investigated.

Q4. Practical approaches and steps your organization have taken to improve IT infrastructure with the aim of enhancing the use of technology to add value to very customer base as a strategic asset. 
International Journal of Business Management and Economic Review

Vol. 4, No. 05; 2021

ISSN: 2581-4664

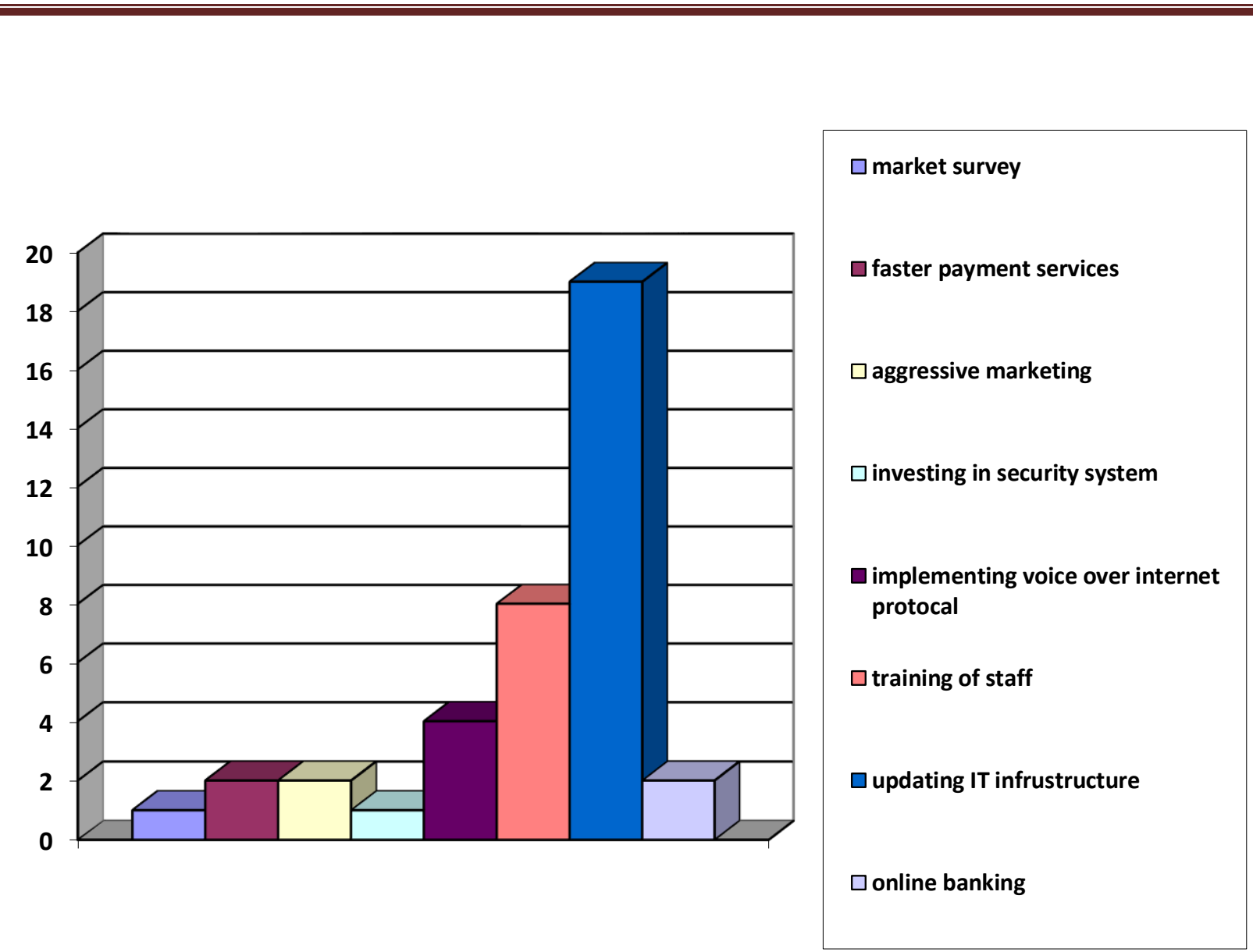

Figure 4.2

As in Figure 4.2, majority of respondent have the view that SACCOs must improve on their investment in updating IT infrastructure. This can be either through integration of M-Pesa to organization bank accounts, update on computer hardware and software, improving on server capacity and storage space, increasing wi-fi capability by choosing reliable internet providers, adding more servers to increase capacity, and creating backups for IT system. The SACCOs should set up more data recovery centers.

Other important approaches include training of staff in areas like computer and computer connectivity through internet. SACCOs must train staff also in performance of computer checkups, and current technology and trends. Other mentioned approaches include proper market survey, marketing of online services to customers, investing on security system for example the use of USSID codes to improve customer interaction with staff, internet banking.

Q5. Measures taken for implementing transformational technologies in your organization to 
International Journal of Business Management and Economic Review

Vol. 4, No. 05; 2021

ISSN: 2581-4664

build leaner business processes, develop innovative products, automate tasks, and minimize costs as a strategic choice towards acquiring, retaining, and winning back customers.

Table 4.4

\begin{tabular}{|c|c|c|c|}
\hline & $\mathrm{N}$ & Mean & $\begin{array}{l}\text { Std. } \\
\text { Deviati } \\
\text { on }\end{array}$ \\
\hline $\begin{array}{l}\text { The customers use self-service to research and troubleshoot issues } \\
\text { by themselves. }\end{array}$ & 145 & 3.2727 & 1.20605 \\
\hline $\begin{array}{l}\text { Tracking employee's movement and working habits, and reducing } \\
\text { building management and utility cost }\end{array}$ & 145 & 3.7879 & 1.08275 \\
\hline $\begin{array}{l}\text { Conducting customer analyses and personalized customer } \\
\text { experience based on individual customer profile }\end{array}$ & 145 & 3.8485 & 1.09320 \\
\hline Building up internal talents & 145 & 3.8788 & 1.08275 \\
\hline $\begin{array}{l}\text { Have host of data and storage services to help them manage } \\
\text { everything }\end{array}$ & 145 & 3.9091 & .94748 \\
\hline Flexible, scalable systems that speed releases IT products & 145 & 4.0303 & .95147 \\
\hline Integrated plan that that highlights risk and dependencies beyond IT & 145 & 4.0303 & .80951 \\
\hline Introduction of new products and services & 145 & 4.1212 & 69631 \\
\hline Maximization of operational efficiency and employee experience & 145 & 4.1212 & 64988 \\
\hline Agile working method & 145 & 4.1515 & .50752 \\
\hline Advocacy for end user & 145 & 4.1515 & 93946 \\
\hline Self-service that provides positive customer experience & 145 & 4.1515 & .83371 \\
\hline Shaping strategy and streaming operation & 145 & 4.1818 & 63514 \\
\hline Taking responsibility for initiatives that generates revenue & 145 & 4.2424 & .75126 \\
\hline $\begin{array}{l}\text { Have better customer self-service portal, that highlights most } \\
\text { popular FAQs (Frequently Asked Questions) }\end{array}$ & 145 & 4.2424 & .90244 \\
\hline
\end{tabular}

From Table 4.4, the measures taken and are working towards implementation of transformational technologies in SACCOs to build leaner business processes, develop innovative products, automate tasks, and minimize costs as a strategic choice towards acquiring, retaining, and winning back customers include: better customer self-service portal, that highlights most popular FAQs, taking responsibility for initiatives that generates revenue, shaping strategy and streaming operation, self-service that provides positive customer experience, advocacy for end user, agile working method, maximization of operational efficiency and employee experience, introduction of new products and services, introduction of new products and services, and flexible, scalable systems services and personalized customer experience based on individual customer profile.

However, the finding showed the following not to be supporting the implementation of transformational technologies in SACCOs to build leaner business processes, develop innovative products, automate tasks, and minimize costs as a strategic choice towards acquiring, retaining, and winning back customers: the customers use self-service to research and troubleshoot issues by themselves, tracking employee's movement and working habits, and reducing building management and utility cost, building up internal talents, having host of data and storage services to help them manage everything, and having host of data and storage services to help them manage everything. 
International Journal of Business Management and Economic Review

Vol. 4, No. 05; 2021

ISSN: 2581-4664

Q6. Implementing transformational technologies in the enterprise to build leaner business processes, develop innovative products, automate tasks, and minimize costs have played a positive role in improving the mentioned customer asset management achievements.

Table 4.5

\begin{tabular}{|llll|}
\hline & & & $\begin{array}{l}\text { Std. } \\
\text { Deviati } \\
\text { on }\end{array}$ \\
\hline Artificial intelligence & $\mathrm{N}$ & Mean & on \\
Customer self-help & 145 & 3.818 & .84611 \\
& & 2 & \\
Continued experimentation and innovation & 145 & 4.090 & .80482 \\
& & 9 & \\
Customer portfolio management & 145 & 4.212 & .73983 \\
& & 1 & 1 \\
& 145 & 4.303 & .63663 \\
\hline
\end{tabular}

Table 4.5 show that in the effort to implement transformational technologies to build leaner business processes, develop innovative products, automate tasks, and minimize costs with a view of improving the customer asset management, The SACCOs have been successful in customer portfolio management, continuous experimentation and innovation and customer self-help. However, artificial intelligence adoption has not been a success.

Q8. Kindly comment on the practical approaches and steps your organization has taken to improve IT Transformational application with the aim of enhancing the use of technology to add value to customer base as a strategic asset. 
International Journal of Business Management and Economic Review

Vol. 4, No. 05; 2021

ISSN: $2581-4664$

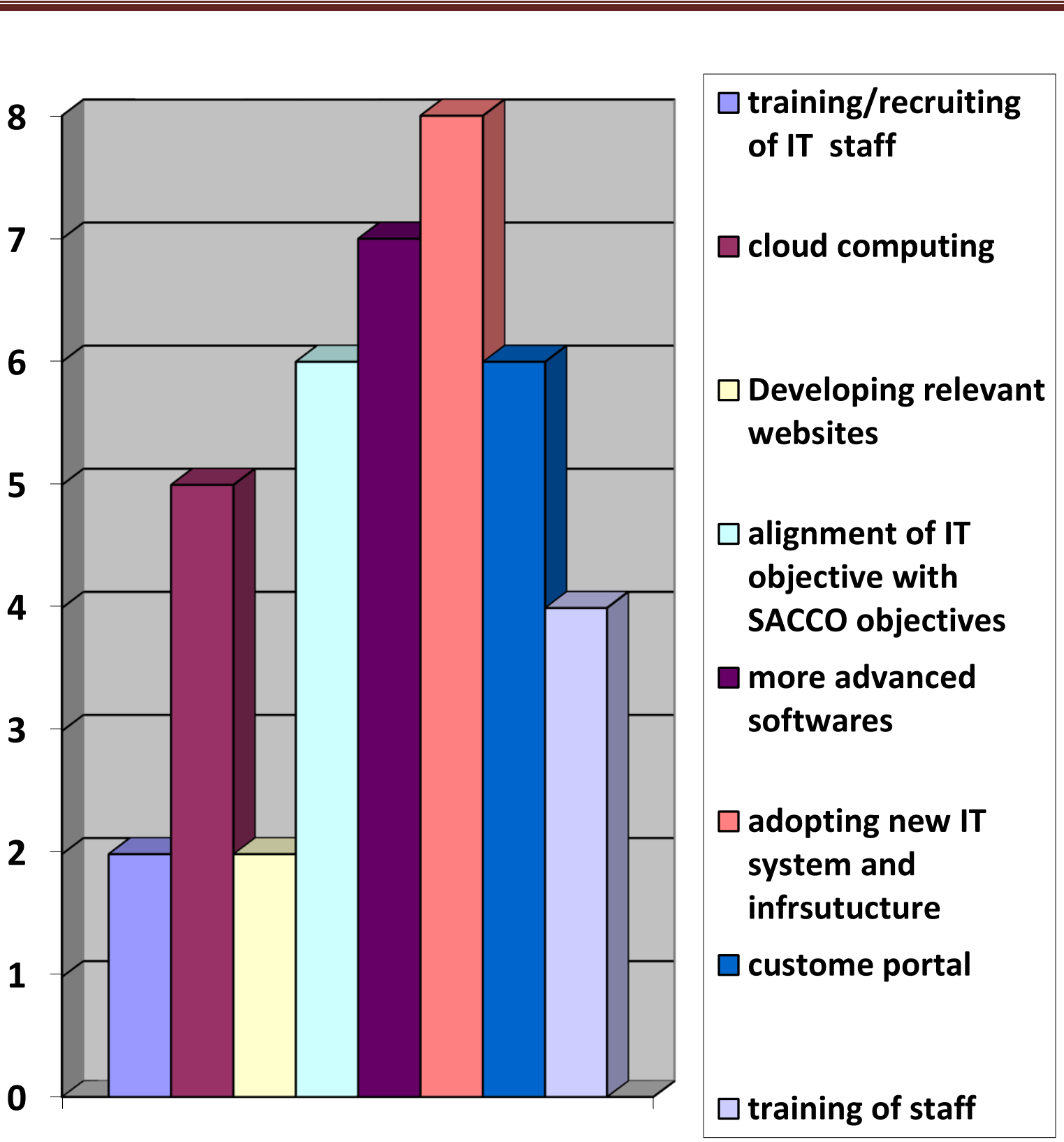

Figure 4.3

Figure 4.3, the respondent had the view that for SACCOs should reengineer IT transformational application with the aim of enhancing the use of technology to add value to customer based as a strategy, they must most importantly adopt new IT systems and infrastructure. Similarly, they need to provide customer portal that helps them access information directly. The SACCOs must align IT objective to the organization objective. Similarly, these institutions need to develop websites that fits on all platforms to enhance and ease communication. They must embrace a 


\section{International Journal of Business Management and Economic Review}

Vol. 4, No. 05; 2021

ISSN: 2581-4664

process of best IT personnel and training them on emerging technologies. Training of staff on safer IT practices and implementation of cloud computing and cloud working platform is also considered important. Th creation of new feature that are focuses on self-help to ensure customer can sort their issues on online portal. There was also a proposal for education and user-friendly transformational application. The SACCOs need to switch to more advanced software's that can improve efficiency and better IT experience and ensuring one stop application for organization and functional website. There should be frequent update of the website and software. Online banking, customer website management and improved customer service is also crucial. There should also be frequent review of current processes and tasks since these clear areas to improve customers experience by reducing time of operations.

Q9. Factors in integrating the results of analytics within the master data environment supplements and analytical applications with real-time characteristics; that involve creation, notification, classification, modification, and validation as a strategic choice towards acquiring, retaining and winning back customers in your organization.

Table 4.6

\begin{tabular}{|llll|}
\hline & & & \multicolumn{2}{l|}{$\begin{array}{l}\text { Std. } \\
\text { Deviatio } \\
\end{array}$} \\
& $\mathrm{N}$ & Mean \\
\hline Best practice community & 145 & 4.0000 & .82916 \\
Fraud analysis & 145 & 4.0000 & .93541 \\
Customer profitability system & 145 & 4.0303 & .84723 \\
Better view into product data and supply chain inventory & 145 & 4.1212 & .78093 \\
New product development & 145 & 4.1212 & .81997 \\
Better view into sales data & 145 & 4.1515 & .79535 \\
Better view into customer relationship & 145 & 4.1818 & .91701 \\
Better understanding of customer behavior & 145 & 4.2121 & .85723 \\
Reengineering business processes & 145 & 4.2121 & .81997 \\
Regular compliance & 145 & 4.2424 & .90244 \\
Better view into financial data & 145 & 4.2424 & .79177 \\
Good reporting & 145 & 4.4242 & .66287 \\
\hline
\end{tabular}

From Table 4.6, The SACCOs have made tremendous effort in integrating the results of analytics within the master data environment supplements and analytical applications with real-time characteristics; that involves creation, notification, classification, modification, and validation as a strategic choice towards acquiring, retaining and winning back customers in your organization by most importantly good reporting. Better view into financial data, regular compliance, reengineering business processes, better understanding of customer behavior, better view into customer relationship, better view into sales data, new product development, better view into product data and supply chain inventory, customer profitability system, fraud analysis and best practice community.

Q10. Integrating the results of analytics within the master data environment supplements analytical applications with real-time characteristics, that involve creation, notification, classification, modification, and validation have played a positive role in improving customer asset management. 
International Journal of Business Management and Economic Review

Vol. 4, No. 05; 2021

ISSN: 2581-4664

Table 4.7

\begin{tabular}{|lllll|}
\hline & & & \multicolumn{3}{l|}{$\begin{array}{l}\text { Std. } \\
\text { Deviatio } \\
\end{array}$} & $\mathrm{N}$ & Mean & $\mathrm{n}$ \\
\hline Has enabled fraud analysis & 14 & 4.0000 & .93541 \\
Advanced Risk Analysis & 5 & & \\
& 14 & 4.2121 & .89294 \\
High Service quality analysis & 5 & & \\
& 14 & 4.2121 & .81997 \\
Improved Customer Analysis & 5 & 14 & 4.2727 & .76128 \\
\hline
\end{tabular}

From Table 4.7, the SACCOs have ensured improved customer analysis, high service quality analysis, advanced risk analysis and has enabled fraud analysis to improve on customer asset management.

Q11. Practical approaches and steps your organization have taken to improve IT analytical application with the aim of enhancing the use of technology to add value to very customer base as a strategic asset.

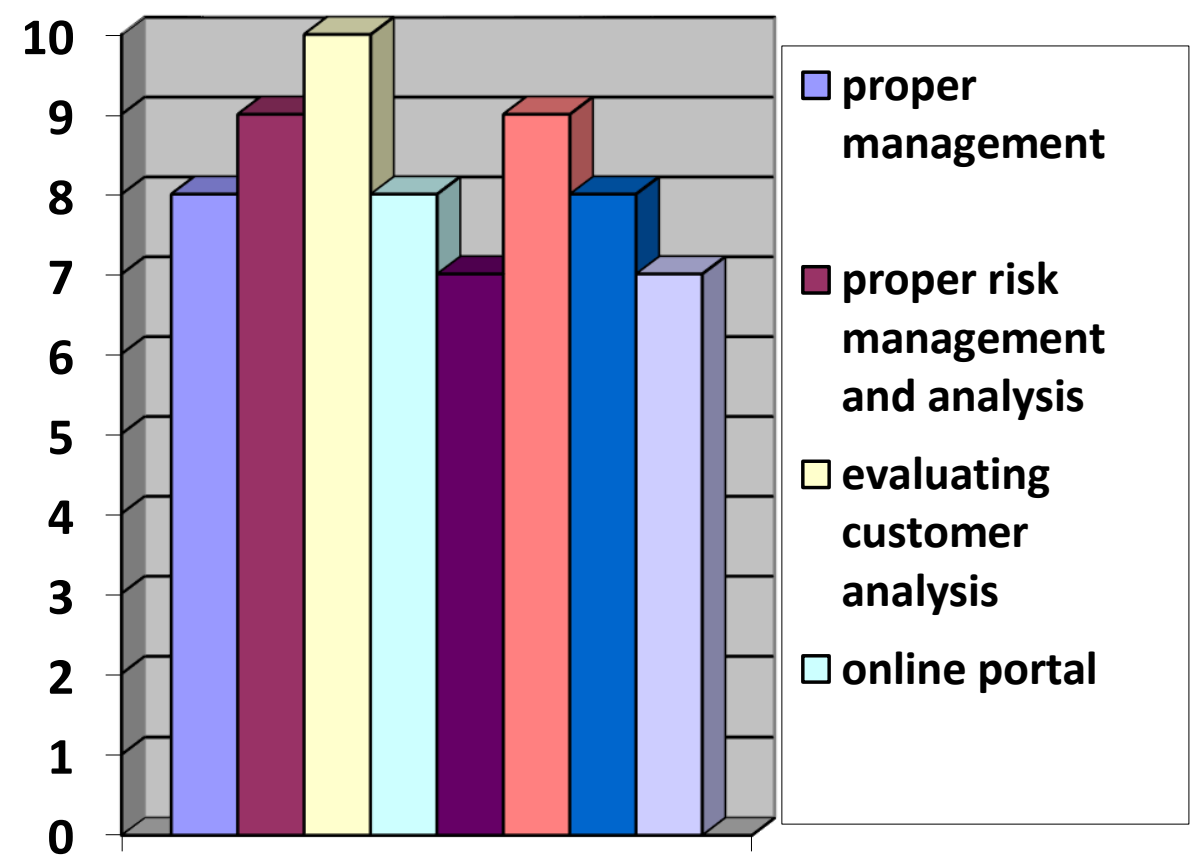

Figure 4.4 
Vol. 4, No. 05; 2021

ISSN: 2581-4664

From Figure 4.4, SACCOs have taken a number of steps to improve on IT analytical application. These include: analysis compliants that come in through various ptalforms like FAQ and customer contact cnters, use of technology in integrating information and also enabling customers to access information and services,teaching of staff on new advancement in IT, proper reporting and regular/ periodic compliance, implementation of efficient and new intergrated financial system, improved customer communication, training of staff on new systems, filtering of websites, installation of new sage and work books application to trach custome rpayments details, proper management of cricism, compliance analysis and content support,good reporting, better view on financial and sales data,development of user friendly web visualization front-end, proper debt and risk management, inatalling systems that can analyse all transactions thus enabling customers, and the use of softwares like firewalls to improve security and reduce fraud. Q12. Factors in system collects and stores data about (of business) transactions and sometimes controls decisions made as part of a transaction.

\section{Table 4.8}

\begin{tabular}{|c|c|c|c|}
\hline & $\mathrm{N}$ & Mean & $\begin{array}{l}\text { Std. } \\
\text { Deviatio } \\
\mathrm{n}\end{array}$ \\
\hline Front end teller productivity tools & $\begin{array}{l}14 \\
5\end{array}$ & 4.0000 & 90139 \\
\hline Monitoring and real time screening of noncustomers & $\begin{array}{l}14 \\
5\end{array}$ & 4.0000 & 1.00000 \\
\hline Integrated customer profile & $\begin{array}{l}14 \\
5\end{array}$ & 4.0606 & .70442 \\
\hline Problem management system & $\begin{array}{l}14 \\
5\end{array}$ & 4.1515 & .79535 \\
\hline Customized report of financial health & $\begin{array}{l}14 \\
5\end{array}$ & 4.1818 & .63514 \\
\hline Managing system resources & $\begin{array}{l}14 \\
5\end{array}$ & 4.2121 & .59987 \\
\hline Scheduling and load balancing & $\begin{array}{l}14 \\
5\end{array}$ & 4.2121 & .64988 \\
\hline Incident tracking system & $\begin{array}{l}14 \\
5\end{array}$ & 4.2121 & .69631 \\
\hline Managing communication & $\begin{array}{l}14 \\
5\end{array}$ & 4.2424 & .70844 \\
\hline Batch transaction processing & $\begin{array}{l}14 \\
5\end{array}$ & 4.3030 & .58549 \\
\hline Credit processing & $\begin{array}{l}14 \\
5\end{array}$ & 4.3030 & .76994 \\
\hline Cash management & $\begin{array}{l}14 \\
5\end{array}$ & 4.3333 & .59512 \\
\hline Check management & $\begin{array}{l}14 \\
5\end{array}$ & 4.3333 & .54006 \\
\hline Real time transaction processing & 14 & 4.3636 & .60302 \\
\hline
\end{tabular}


International Journal of Business Management and Economic Review

Vol. 4, No. 05; 2021

ISSN: 2581-4664

\begin{tabular}{|llll|}
\hline \multirow{2}{*}{ Account performance report generation } & 5 & & \\
& 14 & 4.3636 & .69903 \\
\hline
\end{tabular}

From Table 4.8, the finding show that the SACCOs are engaged in account performance report generation, real time transaction processing, check management, cash management, credit processing, batch transaction processing, management communication, incident tracking system, scheduling and load balancing, management system resources, customized report of financial health, problem management system, integrated customer profile, monitoring and real time screening of non customers and front teller productivity tools.

Q13. Processing system collects and stores data about (of business) transactions and sometimes controls decisions made as part of a transaction.

Table 4.9

\begin{tabular}{|c|c|c|c|}
\hline & $\mathrm{N}$ & Mean & $\begin{array}{l}\text { Std. } \\
\text { Deviatio } \\
\mathrm{n}\end{array}$ \\
\hline Automatic disbursement of payment system & $\begin{array}{l}14 \\
5\end{array}$ & 4.3333 & .81650 \\
\hline Customer profile integration & $\begin{array}{l}14 \\
5\end{array}$ & 4.3333 & .59512 \\
\hline Cash management & $\begin{array}{l}14 \\
5\end{array}$ & 4.4545 & .50565 \\
\hline Credit management & $\begin{array}{l}14 \\
5 \\
\end{array}$ & 4.4545 & .61699 \\
\hline
\end{tabular}

From Table 4.9, Processing system collects and stores data about transactions and sometimes controls decisions made as part of a transaction concerning credit management, cash management, customer profile integration and automatic disbursement of payment system.

Q14. Practical approaches and steps your SACCOs has taken to improve IT transactional processing application with the aim of enhancing the use of technology to add value to very customer base as a strategic asset.
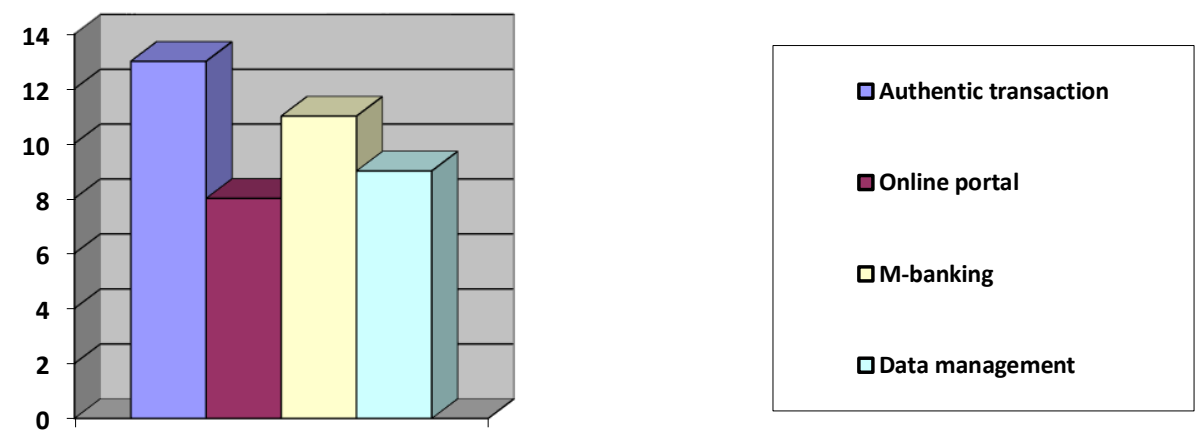


\section{Figure 4.5}

From figure 4.5, the respondend proposal include the use of batch numbers to identify authentic trasaction (batch trasaction processing), trainning of staff and real time payment update, posting of monthly deposits to individual ledger accounts, use of online portal, installation of softwares that can increase efficiency and reliablity of data processing, maintaining know your customer $(\mathrm{KYK})$, and information online with pass word, real time information,online payments, managing communication, incident tracking system, cheque management, account performance reporting generation, customised report of financial health, interation of m-banking with debtors data base to enable real time payment of debts, protection of valuable data through effective systems, storage of data through cloud enabled infrastructure, management of system resource, checking customer profile, and having account report generation, and ensuring application interface is easily navigable with simple features for easy use.

Q15. The use of technology to add value to very customer base as a strategic asset.

Table 4.10

\begin{tabular}{|c|c|c|c|}
\hline & $\mathrm{N}$ & Mean & $\begin{array}{l}\text { Std. } \\
\text { Deviatio } \\
\text { n }\end{array}$ \\
\hline Increased revenue & $\begin{array}{l}14 \\
5\end{array}$ & 4.0909 & .97991 \\
\hline Customer experience utilization & $\begin{array}{l}14 \\
5\end{array}$ & 4.0909 & .84275 \\
\hline Enabled automated real time visibility of customers & $\begin{array}{l}14 \\
5\end{array}$ & 4.1818 & .95048 \\
\hline Decreased cost & $\begin{array}{l}14 \\
5\end{array}$ & 4.1818 & .88227 \\
\hline Optimized overall resource utilization & $\begin{array}{l}14 \\
5\end{array}$ & 4.2121 & .85723 \\
\hline Customer retention and development & $\begin{array}{l}14 \\
5\end{array}$ & 4.2121 & .78093 \\
\hline Customer portfolio management & $\begin{array}{l}14 \\
5\end{array}$ & 4.2727 & .62614 \\
\hline Customer acquisition & $\begin{array}{l}14 \\
5\end{array}$ & 4.3030 & .72822 \\
\hline Customer analysis & $\begin{array}{l}14 \\
5 \\
\end{array}$ & 4.3333 & .81650 \\
\hline
\end{tabular}

From Table 4.10, the SACCOs have achieved the following in their attempt to add value to very customer base as a strategic asset: customer analysis, customer acquisition, customer portfolio management, customer retention and development, optimized overall resource utilization, decreased costs, enabled automated real time visibility of customers, customer experience utilization, and increased revenue.

Q16.Thing SACCOs must improve as far as customer asset management is concerned. 
International Journal of Business Management and Economic Review

Vol. 4, No. 05; 2021

ISSN: 2581-4664

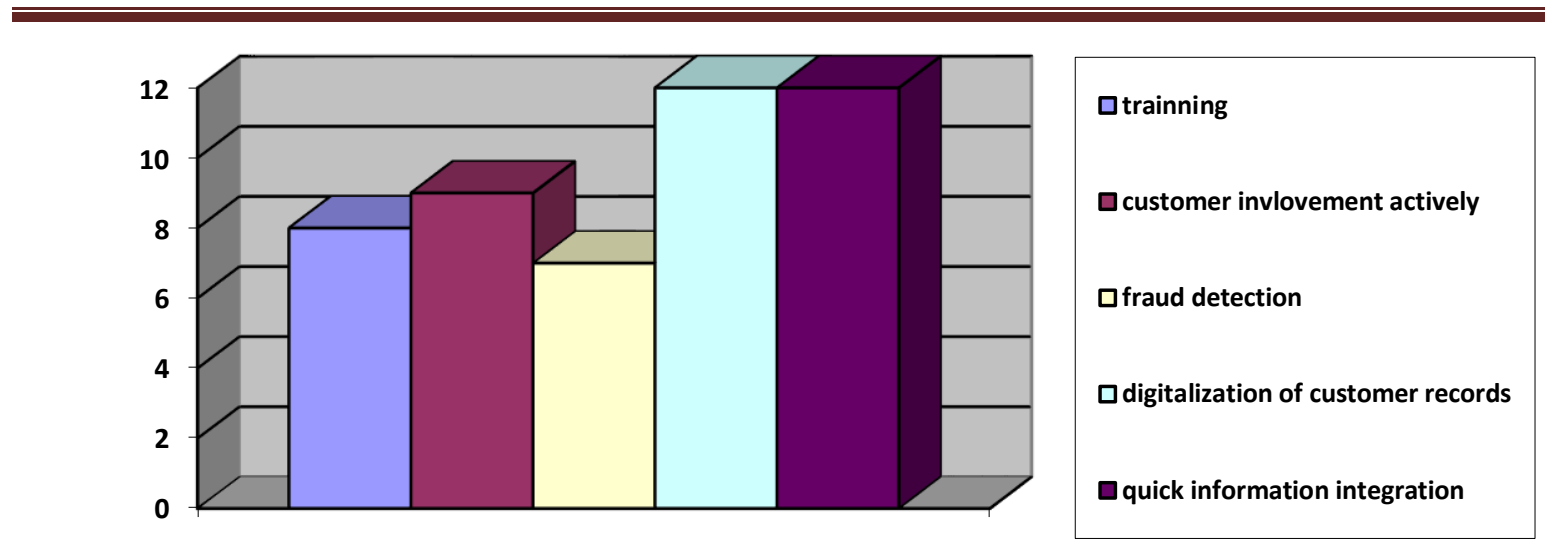

\section{Figure 4.5}

From Figure 4.5 The SACCOs must ensuring that there is efficient reduction in frequency of system down time, and system that is secure to reduce fraud cases. Customer education and userfriendly platform, good management system that captures customer data and payments real time online, customer analysis management information system, develop strong system that can protect, maintain and assess risks involved in controlling customers information. Enabling systems to detect any fraud that might lead to customer loss. Training of staff to have insight and knowledge on threats, and update of security sites. Addition of more servers, training of staff, implementation and application of customer experience database, and customer categorization. Customer experience utilization. Digitalization of all customer records, quick information integration, automation of sales force, encouraging customer participation and more customer survey.

\subsubsection{Regression Analysis}

$Y=\beta_{0}+\beta_{1} X_{1}+\beta_{2} X_{2}+\beta_{3} X_{3}+\beta_{4} X_{4}+\varepsilon$,

Model 1

Where $\mathrm{Y}=$ Customer Asset management by licensed deposit taking SACCOs in Kenya; $\mathrm{X}_{1}=\mathrm{IT}$ infrastructure; $\mathrm{X}_{2}=\mathrm{IT}$ transformational application; $\mathrm{X}_{3}=\mathrm{IT}$ analytical application; $\mathrm{X}_{4}=\mathrm{IT}$ transactional processing application; $\varepsilon=$ error term. Table 4.11 presents a summary of the model 1.

Table 4.11

\begin{tabular}{|llllll|}
\hline $\begin{array}{l}\text { Mode } \\
1\end{array}$ & $\mathrm{R}$ & $\mathrm{R}$ Square & Adjusted R Square & $\begin{array}{l}\text { Std. Error of the } \\
\text { Estimate }\end{array}$ \\
\hline 1 & $.761(\mathrm{a})$ & .579 & .519 & .45963 & \\
\hline
\end{tabular}

a Predictors: (Constant), IT Transactional Processing Application, IT Infrastructure, IT Transformational Application, IT Analytical Application

From Table 4.11, R-Square is 0.579 , which indicates the model explains the $51.9 \%$ of customer asset management. R-Square of above 0.25 is considered fit for social science research (Kariuki \& Rotich, 2017).

Table 4.12 ANOVA(b)

\begin{tabular}{|lllllll|}
\hline Model & & Sum & of & & & \\
\hline 1 & Regression & 8.145 & 4 & 2.036 & 9.639 & Sig. \\
\hline
\end{tabular}


International Journal of Business Management and Economic Review

Vol. 4, No. 05; 2021

ISSN: 2581-4664

\begin{tabular}{|llll|}
\hline \hline Residual & 5.915 & 140 & .211 \\
Total & 14.061 & 144 & \\
\hline
\end{tabular}

a Predictors: (Constant), IT Transactional Processing Application, IT Infrastructure, IT Transformational Application, IT Analytical Application

b Dependent Variable: Customer Asset management

From Table 4.12, The statistical significance of the regression model is 0.000 which is much lower than the study level of significance 0.05 . This indicate that the overall model statistically predicts the outcome variable customer asset management by licensed deposit taking SACCOs in Kenya.

\subsection{Coefficients $(\mathbf{a})$}

\begin{tabular}{|c|c|c|c|c|c|c|}
\hline \multicolumn{2}{|l|}{ Model } & \multicolumn{2}{|c|}{$\begin{array}{l}\text { Unstandardized } \\
\text { Coefficients }\end{array}$} & $\begin{array}{l}\text { Standardize } \\
\mathrm{d} \\
\text { Coefficient } \\
\mathrm{s}\end{array}$ & $\mathrm{t}$ & Sig. \\
\hline \multirow[t]{5}{*}{1} & (Constant) & $\begin{array}{l}\text { B } \\
.189\end{array}$ & $\begin{array}{l}\text { Std. Error } \\
.826\end{array}$ & Beta & .229 & .821 \\
\hline & IT Infrastructure & .429 & .131 & .498 & $\begin{array}{l}3.26 \\
5\end{array}$ & .003 \\
\hline & $\begin{array}{l}\text { IT Transformational } \\
\text { Application }\end{array}$ & -.096 & .171 & -.081 & -.564 & .578 \\
\hline & $\begin{array}{l}\text { IT } \\
\text { Application }\end{array}$ & .254 & .163 & .249 & $\begin{array}{l}1.56 \\
1\end{array}$ & .130 \\
\hline & $\begin{array}{l}\text { IT } \quad \text { Transactional } \\
\text { Processing Application }\end{array}$ & .373 & .184 & .280 & $\begin{array}{l}2.03 \\
3\end{array}$ & .052 \\
\hline
\end{tabular}

a Dependent Variable: Customer Asset management

From Table 4.13, the ANOVA tests the significance of individual independent variable.

a. To examine the influence of IT infrastructure on customer asset management by SACCOs licensed to undertake deposit-taking in Kenya.

As shown in the Table 4.13, the t-statistics for IT infrastructure yield a p-value of 0.003 . Since pvalue is less than 0.05 , we reject the null hypothesis and conclude there is a significant relationship between IT infrastructure and customer asset management by SACCOs licensed to undertake deposit-taking in Kenya.

b. To evaluate the influence of IT transformational application on customer asset management by SACCOs licensed to undertake deposit-taking in Kenya.

As shown in the Table 4.13, the t-statistics for IT transformational application yield a p-value of 0.578 . Since $\mathrm{p}$-value is greater than 0.05 , we fail to reject the null hypothesis and conclude there is no significant relationship between IT transformational application and customer asset management by SACCOs licensed to undertake deposit-taking in Kenya.

c. To determine the influence of IT analytical application on customer asset management by SACCOs licensed to undertake deposit-taking in Kenya.

As shown in the Table 4.13, the t-statistics for IT analytical application yield a p-value of 0.130 . 
International Journal of Business Management and Economic Review

Vol. 4, No. 05; 2021

ISSN: 2581-4664

Since p-value is greater than 0.05 , fail to reject the null hypothesis and conclude there is no significant relationship between IT analytical application and customer asset management by SACCOs licensed to undertake deposit-taking in Kenya.

d. To assess the influence of IT transaction processing application on customer asset management by SACCOs licensed to undertake deposit-taking in Kenya.

As shown in the Table 4.13, the t-statistics for IT transactional processing application yield a pvalue of 0.052 . Since p-value is approximately equal to 0.05 , we reject the null hypothesis and conclude there is significant relationship between IT Transactional Processing Application and customer asset management by SACCOs licensed to undertake deposit-taking in Kenya.

\subsubsection{Estimated Regression Equation}

Based on Table 4.13, the estimated regression equation was:

$\mathrm{Y}=0.189+0.429 \mathrm{X}_{1}-0.096 \mathrm{X}_{2}+0.254 \mathrm{X}_{3}+0.373 \mathrm{X}_{4}+0.45963$.

The equation shows that IT transformational application has a negative influence on customer asset management. with beta coefficient (0.096), suggesting that improving IT transformation application by 1 unit would lead to a decrease in customer asset management by 0.096 . IT infrastructure has the highest influence on customer management with a beta coefficient of 0 . 429. This is followed by IT transactional processing application with a beta coefficient of 0.373 .

\section{SUMMARY OF FINDINGS}

The SACCOs conduct customer analysis, automated real time visibility of customers, customer experience utilization and customer portfolio management in order to achieve customer acquisition, retention and development, and optimized resource utilization, decreased costs, and increased revenue. The SACCOs must ensuring that there is efficient reduction in frequency of system down time, customer education and user-friendly platform, good management system that captures customer data and online real time payments, customer analysis management information system, strong system that is able to protect, maintain and assess risks involved in controlling customers information. They also have adopted systems to detect fraud. Training of staff on threats and update of security sites. They also engage in implementation and application of customer experience database and customer categorization and experience utilization.

a. To examine the influence of IT infrastructure on customer asset management by SACCOs licensed to undertake deposit-taking in Kenya.

Finding showed that there is a significant relationship between IT infrastructure and customer asset management by SACCOs licensed to undertake deposit-taking in Kenya. It has enabled the SACCOs IT personnel to quickly learn and apply new knowledge, leading to achievement of enhanced performance. Through it, SACCOs will achieved strategic reduction in information storage costs, improved information management, increase flexibility, and near-certain backup. For example, the biggest challenge that has faced SACCOs today in cheque clearing (some members must wait for up to seven days), Sidian bank has invented remote cheque scanner (RCC) that makes every cheque presented by SACCO members scanned and cleared immediately. Such innovativeness put SACCOs at the same competitive edge with banks.

The findings have shown SACCOs have failed develop proper systems that are able to configure themselves and heal themselves. Similarly, they lack enough computing power for current and future needs. Data across applications and operating systems have no sufficient consistency and integrity and cannot be shared across applications and operating systems. Less sophisticated 


\section{International Journal of Business Management and Economic Review}

Vol. 4, No. 05; 2021

ISSN: 2581-4664

computers are also now being used for tasks requiring extremely rapid and complex calculations with thousands of variables, millions of measurements. The finding further showed that extraordinary efforts are not being properly taken to make redundant copies of digital information, and placing it on separate secure servers, even remote servers in separate facilities. The findings further show that there is insufficient implementation of hardware/software that are reputable or based on current technological trends. The use of IT infrastructure to analyze direct and indirect costs that help determine the actual cost of owning a specific technology is not yet affected. Further SACCOs have insufficient computer processing, storage, and network resources to handle surging volumes of digital transactions and to make such data immediately available online. The hardware/software is also not easily and quickly adapted for changing needs and standards. Similarly, the SACCOs have not enough computer power for current and future needs.

b. To evaluate the influence of IT transformational application on customer asset management by SACCOs licensed to undertake deposit-taking in Kenya.

There is no significant relationship between IT transformational application and customer asset management by SACCOs licensed to undertake deposit-taking in Kenya. The measures taken and are working towards implementation of transformational technologies in SACCOs to build leaner business processes, develop innovative products, automate tasks, and minimize costs as a strategic choice towards acquiring, retaining, and winning back customers include: better customer self-service portal, that highlights most popular FAQs, taking responsibility for initiatives that generates revenue, shaping strategy and streaming operation, self-service that provides positive customer experience, advocacy for end user, agile working method, maximization of operational efficiency and employee experience, introduction of new products and services, introduction of new products and services, and flexible, scalable systems services and personalized customer experience based on individual customer profile. The finding show there is inefficient customers use of self-service to research and troubleshoot issues by themselves, no tracking employee's movement and working habits, and increasing management and utility cost, no building up of internal talents, no data and storage services to help SACCOs manage everything.

c. To determine the influence of IT analytical application on customer asset management by SACCOs licensed to undertake deposit-taking in Kenya.

There is no significant relationship between IT analytical application and customer asset management by SACCOs licensed to undertake deposit-taking in Kenya. However, the SACCOs have made tremendous effort in integrating the results of analytics within the master data environment supplements and analytical applications with real-time characteristics; that involves creation, notification, classification, modification, and validation as a strategic choice towards acquiring, retaining and winning back customers in your organization by most importantly good reporting. Better view into financial data, regular compliance, reengineering business processes, better understanding of customer behavior, better view into customer relationship, better view into sales data, new product development, better view into product data and supply chain inventory, customer profitability system, fraud analysis and best practice community.

d. To assess the influence of IT transaction processing application on customer asset management by SACCOs licensed to undertake deposit-taking in Kenya.

There is significant relationship between IT Transactional Processing Application and customer 
International Journal of Business Management and Economic Review

Vol. 4, No. 05; 2021

ISSN: 2581-4664

asset management by SACCOs licensed to undertake deposit-taking in Kenya. Processing system collects and stores data about transactions and sometimes controls decisions made as part of a transaction concerning credit management, cash management, customer profile interaction and automatic disbursement of payment system.

\section{CONCLUSIONS OF THE STUDY}

a. To examine the influence of IT infrastructure on customer asset management by SACCOs licensed to undertake deposit-taking in Kenya.

From the findings, SACCOs are in the business of laying foundation for shared information technology upon which business depends. There is need for SACCOs to significantly operate at optimum. SACCOs grow out of technological changes they can exploit. This technology should be able to affect competitive advantage and the industry structure. It should lead to lower cost or differentiation since it makes feasible innovation and continuous improvement. The operations of the SACCOs are below the success standards for maximum revenue. The SACCOs frailer develop proper systems that can configure themselves and heal themselves result to increased labor cost and decrease in capital cost, hence lower reliability, inflexibility, and low workplace safety. Similarly, the lack enough computing power for current and future needs is an indication of poor innovativeness that is likely to make the SACCOs face liquidity issues caused by high delinquency, low institutional capital and at times ineffective loan policies. Data across applications and operating systems have no sufficient consistency and integrity, and cannot be shared across applications and operating systems, leads to lack of public trust, high expenditure, high no earning assets, and lack of savings and mobilization efforts. The SACCOs are therefore not able to address the need of members especially in this time of COVID 19 effectively. The finding further showed that extraordinary efforts are not being properly taken to make redundant copies of digital information, and placing it on separate secure servers, even remote servers in separate facilities. The findings further show that there is insufficient implementation of hardware/software that are reputable or based on current technological trends. The use of IT infrastructure to analyze direct and indirect costs that help determine the actual cost of owning a specific technology is not yet affected. Further SACCOs have insufficient computer processing, storage, and network resources to handle surging volumes of digital transactions and to make such data immediately available online. The hardware/software is also not easily and quickly adapted for changing needs and standards. Similarly, the SACCOs have not enough computer power for current and future needs. There is some challenge in IT planning and management in SACCOs in Kenya. The swiftness and smoothness to adopt the changing customer and IT infrastructure demand require reengineering.

b. To evaluate the influence of IT transformational application on customer asset management by SACCOs licensed to undertake deposit-taking in Kenya.

From the findings, the way IT transformational application is implemented is having negative though insignificant influence on customer asset management by SACCOs licensed to undertake deposit-taking in Kenya. This call for swift focus on innovation and development that influences SACCOs and their customers relationship. More digitalized platform, customer involvement and more loyal customer base is of essence. SACCOs have to place more emphasis on better customer self-service portal, that highlights most popular frequently asked questions, taking responsibility for initiatives that generates revenue, shaping strategy and streaming operation, 
adopting self-service that provides positive customer experience, advocacy for end user, agile working method, maximization of operational efficiency and employee experience (proper combination of digital speed and convenience), introduction of new products and services, and flexible, scalable systems services and personalized customer experience based on individual customer profile. The study concludes that there is need for efficient customers use of selfservice to research and troubleshoot issues by themselves, tracking employee's movement and working habits, and increasing management and utility cost, building up of internal talents, and establishing data and storage services to help SACCOs manage everything. Information technology should revolutionize the SACCO sector.

c. To determine the influence of IT analytical application on customer asset management by SACCOs licensed to undertake deposit-taking in Kenya.

There is need for total rethink and radical design of the IT analytical application for it to have significant effect on customer asset management. More effort by SACCO is required in integrating the results of analytics within the master data environment supplements and analytical applications with real-time characteristics which involves creation, notification, classification, modification, and validation as a strategic choice towards acquiring, retaining and winning back customers. SACCOs must identify much better view into their financial data, regular compliance, reengineering business processes, better understanding of customer behavior, better view into customer relationship, better view into sales data, new product development, better view into product data and supply chain inventory, customer profitability system, fraud analysis and best practice community.

d. To assess the influence of IT transaction processing application on customer asset management by SACCOs licensed to undertake deposit-taking in Kenya.

IT transactional processing application is crucial in day-to-day routine and is based on system of process the SACCO is using. It collects and store data about transactions and control decisions made. SACCOs need to redefine how they implement IT transaction processing application to improve on customer asset management. Processing system collects and stores data about transactions and sometimes controls decisions made as part of a transaction concerning credit management, cash management, customer profile interaction and automatic disbursement of payment system. No process according to the findings have been performed efficiently hence a great need for total improvement on IT transaction processing application.

\section{RECOMMENDATION OF THE STUDY}

a. To examine the influence of IT infrastructure on customer asset management by SACCOs licensed to undertake deposit-taking in Kenya.

From the conclusions, the study recommends that SACCOs must improve on their investment in updating IT infrastructure. This can be either through integration of M-Pesa to organization bank accounts, update on computer hardware and software, improvement on server capacity and storage space, increasing Wi-Fi capability by choosing reliable internet providers, adding more servers to increase capacity, and creating backups for IT system. The SACCOs should set up more data recovery centers. Other important approaches include training of staff in areas like computer and computer connectivity through internet. SACCOs must train staff also in performance of computer checkups, and current technology and trends. Other recommendations 
International Journal of Business Management and Economic Review

Vol. 4, No. 05; 2021

ISSN: 2581-4664

include proper market survey, marketing of online services to customers, investing on security system for example the use of USSID codes to improve customer interaction with staff, internet banking.

b. To evaluate the influence of transformational application on customer asset management by SACCOs licensed to undertake deposit-taking in Kenya.

The study recommends that SACCOs should improve on IT transformational application with the aim of enhancing the use of technology to add value to customer based as a strategy. Similarly, they need to provide customer portal that helps them access information directly. The SACCOs must align IT objective to the organization objective. Similarly, these institutions need to develop websites that fits on all platforms to enhance and ease communication. They must embrace a process of best IT personnel and training them on emerging technologies. Training staff on safer IT practices and implementation of cloud computing and cloud working platform is also considered important. The creation of new feature that are focuses on self help to ensure customer can sort their issues on online portal. There is also a proposal for education and userfriendly transformational application. The study recommends SACCOs to switch to more advanced software that can improve efficiency and better IT experience and ensuring one stop application for organization and functional website. There should be frequent update of the website and software. Online making, customer website management and improved customer service is also crucial. There should also be frequent review of current processes and tasks since these clear areas to improve customers experience by reducing time of operations. SACCOs need to investigate architectures and standards, IT research and design, and communication protocol and management.

c. To determine the influence of analytical application on customer asset management by SACCOs licensed to undertake deposit-taking in Kenya.

The study recommend that SACCOs should do analysis of compliants that come in through various ptalforms like FAQ and customer contact centers, use of technology in integrating information and also enabling customers to access information and services,teaching of staff on new advancement in IT, proper reporting and regular/ periodic compliance, implementation of efficient and new intergrated financial system, improved customer communication, training of staff on new systems, filtering of websites, installation of new sage and work books application to trach custome rpayments details, proper management of cricism, compliance analysis and content support,good reporting, better view on financial and sales data,development of user friendly web visualization front-end, proper debt and risk management, inatalling systems that can analyse all transactions thus enabling customers, and the use of softwares like firewalls to improve security and reduce fraud. The study also recommend that the SACCOs be engaged in account performance report generation, real time transaction processing, check management, cash management, credit processing, batch transaction processing, management communication, incident tracking system, scheduling and load balancing, management system resources, customized report of financial health, problem management system, integrated customer profile, monitoring and real time screening of non customers and front teller productivity tools.

d. To assess the influence of transaction processing application on customer asset management by SACCOs licensed to undertake deposit-taking in Kenya.

Study recommend for the use of batch to identify authentic trasactions; trainning of staff and real 


\section{International Journal of Business Management and Economic Review}

Vol. 4, No. 05; 2021

ISSN: 2581-4664

time payment update, posting of monthly deposits to idnvidual ledger accounts, use of onlie portal, installation of softwares that can increase efficiency and reliablity of data processing, maintaining know your customer (KYK) and information online with pass word, real time information,online payments,managing communication, incident tracking system, check management, account performance reporting generation, customised report of financial health, interation of m-banking with debtors data base to enable real time payment of debts, protection of valuable data through effective systems, storage of data through cloud enabled infrastructure, management of system resource, checking customer profile, and having account report generation, and ensuring application interface is easily navigatable with simple features for easy use.

\section{REFERENCE}

Amin, M. B., Allaudin, M., \& Azad, M. (2012). Business Transaction Processing System. International Journal of Computer Information Systems , 4 (5), 11-60.

Bank, W. (1998-1999). World development report 1998/1999 : knowledge for development (English). New York: Oxford University Press.

Barney, J., Wright, M., \& Ketchen, D. J. (2001). Resource Based View of the Firm. Journal of Management , 27 (265).

Cisek, S. (2017). Funkcje i role bibliotek naukowych i publicznych w spoleczeństwie wiedzy.

Clinch, G., \& Lombardi, B. Information and the cost of capital:The Easley-O'Hara (2004) model with endogenous information acquisition. Australian Journal of Management , 36 (1), 514.

De Falco, E. S., \& Renzi, A. (2015, April 17). Agency theory, stewardship theory and residual right: logics and interpretative models. Tourism \& Management Studies , pp. 1-41.

Francis, B., \& Marklan, S. (2015). Customer Relationship Management - Concepts and Technologies ( 3 ed.). Routledge: Taylor \& Francis Group.

Galavan, R. J. (2015, August). Understanding Resources, Competences, and Capabilities in EU Common Security and Defence Policy. Working Paper.

Henry-Nickie, M., Frimgpong, K., \& Sun, H. (2019, March 29). Trends in the Information Technology sector. Brookings, p. 1.

Junhong, C. (2015). Customer Asset Management. Instruction Material for MKT3417- Customer Asset Management, pp. 1-4.

Kalakota, R. K., \& Whinston, A. B. (1996). Electronic Commerce: A manager's Guide. New Delhi: Pearson Education, Inc.

Kalakota, R., \& Whinston, A. B. (1997). Electronic Commerce: A manager's guide (Low price edition ed.). New Delhi: Pearson Education.

Karimi, L. (2021, September). SACCO star magazine. Implementing citius core banking solution to drive growth (55).

Kelton, W., \& Scott, G. (2020, March 16). Risk Management in Finance. Investopedia , p. 1

Kenya, P. A.T. (2019). Mugo, David, M; Muathe, Stephen; Waithaka, Stephen, T. International Journal of Information System, 11 (2), 1-17.

Khalid, K., \& Mumar, D. M. (2012). Get along with quantitative research. 2.

Knight, G. A., \& Cavusgil, T. L. (2004, January 8). Innovation, organizational capabilities, and the born-global firm. Springer Link, pp. 214-141.

Kosuga, M., Monden, Y., \& Monden, Y. (2007, January 1). Japanese Management Accounting 


\section{Today. World Scientific, 125.}

Kotter, J. P., \& Schlesinger, L. A. (2008, July-August). Choosing Strategies for Change. Harvard Business Review Home, p. 1.

Kulbytė, T. (2020, July 9). 5 unique ways to increase customer retention (and increase profits!). CRM Online .

Lary, L. (2008). The power of financial ratios indetecting fraudulent reporting: A case of SACCOs in Kenya. Nairobi: KUSCCO.

Laudon. (n.d.). IT Infrastructure and Emerging Technologies. Information Technology Infrustructure, pp. 1-39.

Lorenzo, J. R., Rubio, M. T., \& Garces, S. A. (2018). The competitive advantage in business, capabilities and strategy. What general performance factors are found in the Spanish wine industry? Wine Economics and Policy, 7 (2), 94-108.

Loshin, D. (2009). Master of data management. MDM Paradygm and Architecture .

Loshin, D. (2011). The Practitioner's Guide to Data Quality Improvement. Master Data Management and Data Quality .

Madhani, P. M. (2010, April 5). Resource Based View (RBV) of Competitive Advantage: An Overview. RESOURCE BASED VIEW: CONCEPTS AND PRACTICES , pp. 3-22.

Madhani, P. M. (2020, March). Resource Based View (RBV) of Competitive Advantage: An overview. Research Gate .

Maina, N. J., Kinyariro, D. k., Muturi, H. M., \& Muriithi, M. J. (2016). Credit Information Sharing And Level Of Loan Default In Deposit Taking Saccos In Meru County, Kenya. International Journal of economics, Commerce and Management , 4 (4).

McFarlan, W. F. (1984, May). Information Technology Changes the Way You Compete. Hvard Business Review .

Mclver, D., \& Lengnick-Hall, C. (2017, November 6). The causal ambiguity paradox: Deliberate actions under causal ambiguity. Strategic Organization .

Michaelis, B., Rogbeer, S., Schweizer, L., \& Ozleblebici, Z. (2020, June 29). Clarifying the boundary conditions of value creation within dynamic capabilities framework: a grafting approach. Review of Managerial Science 2020 .

Mugo, M. D., Muathe, S., \& Waithaka, T. S. (2019). Performance Analysis of Debit Card Services on Deposit-Taking SACCOs' Financial Performance:A Case of Kenya. The African Journal of Information System, 11 (2), 1-17.

Mweru, C. M., \& Muya, T. M. (2016). Features of Resource Based View Theory: An Effective Strategy in Outsourcing. International Journal of Management and Commerce Innovations , 3 (2), 215-218.

NIIT (2019). IT Infrastructure Management: The Road to Transforming Business. At the heart of optimizing efficiency: Engage with the emerging .

Odero, K. K. (2003). Extending the Sustainable Livelihoods Framework.

Okoth, J. (2019, December 23). Civil Servants' SACCOs Lead Other SACCOs. The Kenya Wall Street .

Olokundu, M. (2014). The link between the resource based theory and corporate politics. Business Economics , p. 9.

Oracle. (2018). Getting strated with transformational technology. 3 ways to drive your business forward . 


\section{International Journal of Business Management and Economic Review}

Vol. 4, No. 05; 2021

ISSN: 2581-4664

Otieno, S. (2019, May 21). the role of cooperatives in social and economic development of kenya and actions required to accelerate growth and development of the sector in africa. Corporative Alliance of Kenya Limited, pp. 1-13.

Paine, L. S., \& Srinivasan, S. (2019, October 14). A Guide to the Big Ideas and Debates in Corporate Governance. Harvard Business Review Home .

Porter, M. E., \& Millar, V. E. (1985, July). How Information Gives You Competitive Advantage. Havard Business Review .

Reepu. (2015, November 28). Customer Asset Management. International Conference for sustainability-Engineering, informantion technology, management and the environment .

Reeves, M., \& Deimler, M. (2011, July-Agust). Adaptability: The New Competitive Advantage. Harvard Business Review Home, p. 1.

Retrieved August 15, 2020, from: http://www.cbr.edu.pl/konf2005mat/ondex_konf.html

Rose, R. C., Abdullah, H., \& Ismad, A. I. (2010). A Review on the Relationship between Organizational Resources, Competitive Advantage and Performance. The Journal of International Social Research, 3 (11).

Sarokin, D. (2019, May 20). What Are Some Ways in Which Global Forces Affect Business Today? Chrone, p. 1.

SASRA. (2012). SACCO Society Regulatory Authority. Nairobi: Government Printer.

SASRA. (2016). SACCO Societies Regulatory Authority. Nairobi: Government Printer.

Schlesinger, b. J. (2008, July-August). Choosing Strategies for Change. Harvard Business Review Home, p. 1.

Sekaran, U., \& Bougie, R. (2010). Research Methods for Business: A Skill Building Approach (5 ed.). New Jersey: John Wiley and Sons.

Sergio, J. (2011). Strategic Management: The theory and practice of strategy in (business) organizations. DTU Library.

Srivastava, M., Franklin, A., \& Martinette, L. (2013). Building a Sustainable Competitive Advantage. Journal of Technology Management \& Innovation, 8 (2).

Survival strategies for businesses during COVID-19 lockdown. (2020, April 25). Economic Times , p. 1.

System, T. A. (2019). Performance Analysis of Debit Card Services on Deposit-Taking SACCOs' Financial Performance:A Case of Kenya. 11 (2).

Teece, D. (2017, September 8). A capability theory of the firm: an economics and (Strategic) management perspective. New Zealand economic paper , 15 (1), pp. 1-43.

UNESCO. (2002). Information and Communication Technology in Teacher EDUCATION: A Planning Guide. UNESCO.

Wade, M., \& Hulland, J. (2004, March). Review: the resource-based view and information systems research:review, extension, and suggestionsfor future research. MIS Quaterly Review: Resource-Based View of IS Research , 28 (1), pp. 1-xxx.

Wasonga, M. (2020, July 9). How Fast Can Automation Grow SACCOs? CIO East Africa .

Whiteley, D. (2000). e-Commerce: Strategy, Technologies and Applications. New Delhi: McGraw Hill Education (India) Private Limited. 